\title{
Perbandingan spektrum curah hujan harian antara BMKG dan TRMM di DKI Jakarta
}

\author{
Imanuel K. Perangin Angin ${ }^{\mathrm{a}, *}$, Ahmad Zakaria ${ }^{\mathrm{b}}$, Dyah Indriana Kusumastutic \\ ${ }^{a}$ Mahasiswa Magister Teknik Sipil, Universitas Lampung, Jl. Soemantri Brojonegoro No. 1 Bandar Lampung, 35145, Indonesia \\ ${ }^{b}$ Jurusan Teknik Sipil, Universitas Lampung, Jl. Soemantri Brojonegoro No. 1 Bandar Lampung, 35145, Indonesia \\ c Jurusan Teknik Sipil, Universitas Lampung, Jl. Soemantri Brojonegoro No. 1 Bandar Lampung, 35145, Indonesia
}

\section{H I G H L I G H T S}

- Hasil penelitian ini menunjukkan bahwa sangat memungkinkan untuk menggunakan data perkiraan satelit dalam membantu menganalisis konsistensi alat pengukur hujan dan membantu identifikasi curah hujan saat alat pengukur hujan rusak.

- Data curah hujan yang diamati pada alat pengukur hujan konvensional masih memberikan hasil yang lebih baik dan masih merupakan cara yang lebih andal untuk mengukur curah hujan daripada perkiraan satelit, namun dapat menjadi sumber data alternatif untuk simulasi curah hujan.

\section{N F O ARTIKEL}

\section{Riwayat artikel:}

Diterima 25 Maret 2020

Diterima setelah diperbaiki 12 Mei 2020

Diterima untuk diterbitkan 22 Juni 2020

Tersedia secara online 01 Agustus 2020

\section{Kata kunci:}

Alat pengukur curah hujan konvensional, spektrum curah hujan,

stasiun curah hujan,

tropical rainfall measurement mission.

\begin{abstract}
A B S T R A K
Tujuan penelitian ini adalah untuk melihat hubungan korelasi tingkat curah hujan harian dan kumulatif 10 harian antara pengukuran dari stasiun Badan Meteorologi, Klimatologi dan Geofisika (BMKG) dan tropical rainfall measurement mission (TRMM) di Propinsi DKI Jakarta. Dari data curah hujan harian observasi BMKG dan data curah hujan satelit TRMM tersebut dilakukan perhitungan dan analisis menggunakan metode spektral untuk mendapatkan nilai spektrum dari kedua data curah hujan tersebut dengan metode fast fourier transform (FFT) dan dengan bantuan perangkat lunak FTRANS. Setelah nilai amplitudo diperoleh pada kedua data dari MBKG dan TRRM, kedua data dibandingkan untuk mendapatkan nilai hubungan korelasi. Hasil perhitungan spektrum curah hujan harian, nilai korelasi yang didapat di tiga stasiun curah hujan di Provinsi DKI Jakarta sangat lemah yaitu 0,008, 0,101 dan 0,09 untuk masing-masing stasiun Halim Perdana Kusuma, stasiun Kemayoran dan stasiun Tanjung Priok. Sedangkan untuk spektrum curah hujan kumulatif 10 harian, nilai korelasi yang didapat cukup kuat untuk stasiun Kemayoran dan Tanjung Priok yaitu 0,53 dan 0,50.
\end{abstract}

Diterbitkan oleh Jurusan Teknik Sipil Universitas Lampung

\section{Pendahuluan}

Curah hujan merupakan suatu unsur meteorologi yang sulit diprediksi dikarenakan setiap daerah memiliki kondisi geografis yang berbeda-beda, sehingga setiap daerah memiliki keragaman intensitas curah hujan. Selain itu, perbedaan curah hujan di daerah Indonesia dipengaruhi oleh anomali suhu permukaan laut di kawasan laut Indonesia, Samudra Hindia dan kawasan Pasifik [1, 2].

Pola curah hujan di Indonesia umumnya dipengaruhi oleh monsun [3] yang dicirikan dengan adanya perbedaan yang tegas antara musim kemarau dan musim penghujan. Secara keseluruhan, pola hujan yang ada di wilayah Indonesia dibagi menjadi tiga pola yaitu pola monsunal, pola equatorial dan pola lokal. Umumnya, untuk mengamati

\footnotetext{
* Penulis koresponden.
}

Alamat e-mail: iperanginangin@gmail.com

Peer review dibawah tanggung-jawab Jurusan Teknik Sipil -

Universitas Lampung.

https://doi.org/10.23960/rekrjits.v24i2.41 curah hujan yang terjadi di Indonesia dilakukan dengan menggunakan alat pencatat curah hujan (rain gauge) baik secara manual maupun automatis.

Namun, dalam pengamatan terhadap curah hujan yang terjadi di Indonesia, masih ditemukan kendala dan permasalahan baik berupa minimnya ketersediaan data curah hujan observasi baik secara spasial maupun temporal [4]. Kendala permasalahan tersebut diantaranya berupa data time series yang kurang panjang dan tidak lengkap, jumlah stasiun hujan yang kurang tersebar merata, kurangnya tenaga pengamat di stasiun hujan, sistem pengamatan dan pemasukan data yang masih manual. Kendala tersebut menyebabkan data pengamatan hujan masih sulit diperoleh dengan cepat dan tepat. Terkait dengan kendala tersebut di atas, maka diperlukan metode alternatif guna mendapatkan ketersediaan dan tingkat keakuratan data curah hujan tersebut [5]. Untuk itu metode alternatif yang digunakan yaitu dengan membandingkan data curah hujan harian yang ada pada stasiun curah hujan di permukaan dengan data curah hujan harian dari tropical rainfall measurement 
mission (TRMM) dan melihat korelasi kedua data curah hujan tersebut walaupun sering terjadi kesalahan dalam melihat pola hujan [6], kemampuan menangkap medan presipitasi yang tergantung pada sensitivitas presipitation radar (PR) [7], namun menurut Erazo $d k k$. [8] data yang berasal dari TRMM cukup dekat dengan data hasil observasi. Oleh sebab itu, tujuan penelitian ini adalah untuk melihat korelasi spektrum curah hujan harian dan korelasi kumulatif 10 harian curah hujan dari stasiun BMKG dan TRRM di Propinsi DKI Jakarta. Dari penelitian ini diharapkan mendapatkan data curah hujan yang belum mampu dijangkau oleh stasiun curah hujan di daerah tersebut guna menjadi acuan dikemudian hari untuk perencanaan analisis hidrologi.

\section{Metode Penelitian}

Lokasi penilitian ini berada di daerah Propinsi DKI Jakarta, yang memiliki tiga stasiun curah hujan BMKG yang tersebar di daerah Tanjung Priok, Kemayoran dan Halim Perdana Kusuma. Dari ketiga stasiun curah hujan yang ada tersebut masih belum mampu menjangkau daerah-daerah yang ada di Propinsi DKI Jakarta untuk mendapatkan data curah hujan yang valid.

Data yang digunakan dalam penelitian ini adalah data curah hujan harian yang didapat dari Badan Meteorologi, Klimatologi dan Geofisika (BMKG) Propinsi DKI Jakarta dan data curah hujan satelit TRMM dengan titik kordinat sesuai dengan lokasi stasiun curah hujan BMKG di Propinsi DKI Jakarta, tahun 1998 - 2017. Data curah hujan diambil dari ketiga stasiun pengamat curah hujan tersebut di atas yaitu stasiun Kemayoran, stasiun Halim Perdana Kusuma dan stasiun Tanjung Priok.

Kemudian, dari data curah hujan harian observasi BMKG dan data curah hujan satelit TRMM tersebut dilakukan perhitungan dan analisis menggunakan metode spektral untuk mendapatkan nilai spektrum dari kedua data curah hujan tersebut dengan metode FFT (Fast Fourier Transform) dan dengan bantuan perangkat lunak FTRANS. Selain nilai spektrum curah hujan harian, juga dihitung nilai spektrum kumulatif 10 harian, yang kemudian dihitung dan dilihat nilai korelasi pada kedua data, dari BMKG dan TRRM, tersebut. Untuk mendapatkan nilai korelasi spektrum hujan observasi dari stasiun curah hujan terhadap spektrum curah hujan TRMM maka digunakan persamaan nilai korelasi (Persamaan 1).

$$
\mathrm{r}=\frac{n \sum_{i=1}^{n} x_{i} y_{i}-\sum_{i=1}^{n} x_{i} \sum_{i=1}^{n} y_{i}}{\sqrt{n \sum_{i=1}^{n} x_{i}^{2}-\left(\sum_{i=1}^{n} x_{i}\right)^{2}} \sqrt{n \sum_{i=1}^{n} y_{i}^{2}-\left(\sum_{i=1}^{n} y_{i}\right)^{2}}}
$$

dengan $\mathrm{r}$ adalah koefisien korelasi yang dicari, $\sum x y$ adalah jumlah perkalian antara variabel $\mathrm{x}$ dan $\mathrm{y}, \sum x^{2}$ adalah jumlah dari kuadrat nilai $x, \sum y^{2}$ adalah jumlah dari kuadrat nilai y, $\left(\sum x\right)^{2}$ adalah jumlah nilai $x$ kemudian dikuadratkan, $\left(\sum y\right)^{2}$ adalah jumlah nilai y kemudian dikuadratkan dan $\mathrm{n}$ adalah jumlah responden.

Dari analisis korelasi data curah hujan BMKG terhadap data curah hujan TRMM tersebut di atas, kemudian dicari fungsi persamaan kedua data curah hujan tersebut dengan menggunakan analisis regresi (Persamaan 2).

$Y_{i}=a+b X_{i}$

dengan $Y_{i}$ adalah variabel tidak bebas, $a$ adalah variabel intercept, $b$ adalah kemiringan (slope) dan $X_{i}$ adalah variable bebas.

\section{Hasil dan Pembahasan}

Gambar 1 menyajikan spektrum curah hujan harian dari BMKG dan TRRM di stasiun Halim Perdana Kusuma pada tahun 1998. Terdapat hubungan yang tidak kuat antara kedua spektrum tersebut, terlihat dari puncak amplitudo spektrum BMKG dan TRMM yang tidak mendekati. Pada TRMM puncak amplitudo berada di 2,5544 mm sedangkan BMKG berada di 0,9177 mm. Kemudian, Gambar 2 menyajikan model persamaan spektrum curah hujan harian dari BMKG dan TRRM di stasiun Halim Perdana Kusuma pada tahun 1998, $Y=-0,00237 X+0,23523$ dengan nilai $R^{2}$ adalah 0,00004 . Terlihat hubungan korelasi yang tidak kuat antar kedua spektrum curah hujan tersebut. Lalu, Tabel 1 menyajikan fungsi persamaan linier spektrum harian curah hujan BMKG dengan TRMM di stasiun curah hujan Halim Perdana Kusuma, dari tahun 1998 sampai tahun 2017, dengan nilai rata-rata fungsi persamaan yaitu $Y=0,036115 X+0,441266$ dengan nilai $R^{2}$ adalah 0,0082 .

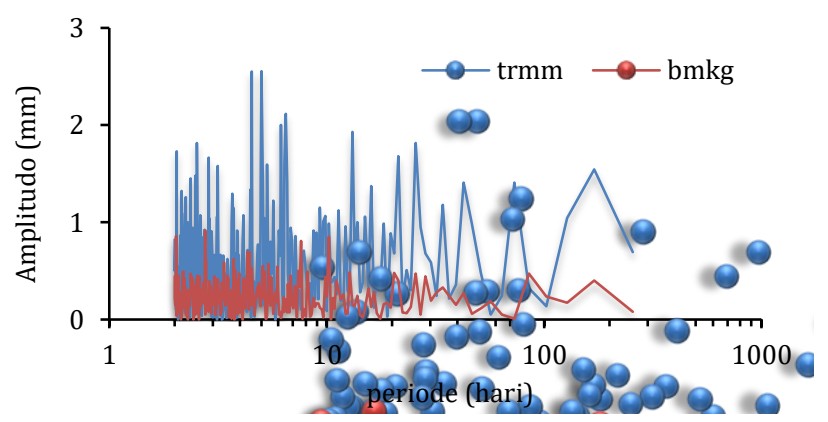

Gambar 1. Spektrum curah hujan harian di stasiun Halim Perdana Kusuma tahun 1998

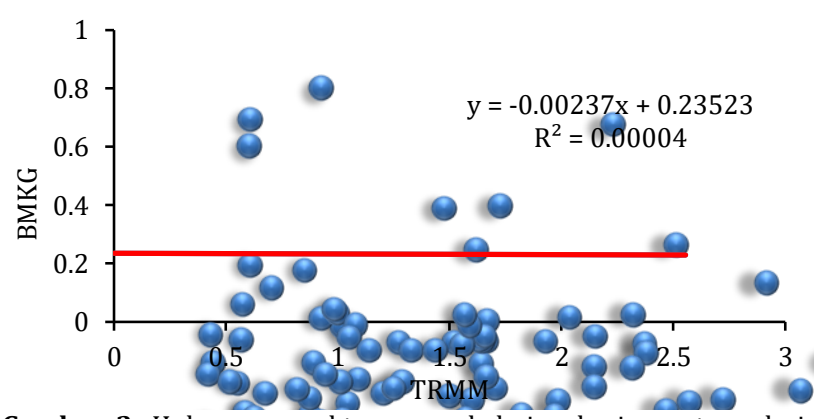

Gambar 2. Hubungan spektrum curah hujan harian antara dari BMKG dan TRMM di stasiun Halim Perdana Kusuma tahun 1998.

Kemudian, Gambar 3 menyajikan spektrum curah hujan harian dari BMKG dan TRRM di stasiun Kemayoran pada tahun 1998. Terdapat hubungan yang tidak kuat antara kedua spektrum tersebut, terlihat dari puncak amplitudo spektrum BMKG dan TRMM yang tidak mendekati. Pada TRMM puncak amplitudo tertinggi berada di $1,9640 \mathrm{~mm}$ sedangkan BMKG berada di 2,6973 mm. Lalu, Gambar 4 menyajikan model persamaan spektrum curah hujan harian dari BMKG dan TRRM di stasiun Kemayoran pada tahun 1998, $Y=0,099 X+0,614$ dengan nilai $R^{2}$ adalah 0,008 . Terdapat hubungan yang tidak kuat antar kedua spektrum tersebut. Kemudian, Tabel 2 menyajikan fungsi persamaan linier spektrum harian curah hujan dari BMKG dan TRMM di stasiun curah hujan Kemayoran, tahun 1998-2017, dengan nilai rata-rata fungsi persamaan yaitu $Y=0,3185 X+$ 0,54045 dan nilai $R^{2}$ adalah 0,10175 . 
Tabel 1

Persamaan linear di stasiun Halim Perdana Kusuma

Tahun Parameter persamaan linear

\begin{tabular}{llll} 
& $a$ & $b$ & $R^{2}$ \\
\cline { 2 - 4 } 1998 & $-0,002$ & 0,235 & 0,00004 \\
1999 & 0,014 & 0,274 & 0,001 \\
2000 & 0,010 & 0,359 & 0,00058 \\
2001 & 0,008 & 0,420 & 0,00027 \\
2002 & 0,061 & 0,332 & 0,019 \\
2003 & 0,038 & 0,246 & 0,012 \\
2004 & 0,040 & 0,271 & 0,016 \\
2005 & 0,029 & 0,407 & 0,004 \\
2006 & 0,034 & 0,676 & 0,002 \\
2007 & 0,061 & 0,674 & 0,008 \\
2008 & 0,083 & 0,444 & 0,015 \\
2009 & 0,044 & 0,490 & 0,002 \\
2010 & 0,002 & 0,425 & 0,00001 \\
2011 & $-0,043$ & 0,387 & 0,004 \\
2012 & 0,152 & 0,566 & 0,032 \\
2013 & 0,043 & 0,904 & 0,002 \\
2014 & 0,080 & 0,462 & 0,015 \\
2015 & 0,071 & 0,347 & 0,028 \\
2016 & $-0,029$ & 0,542 & 0,001 \\
2017 & 0,026 & 0,363 & 0,002 \\
Rata-Rata & 0,036 & 0,441 & 0,008 \\
\hline
\end{tabular}

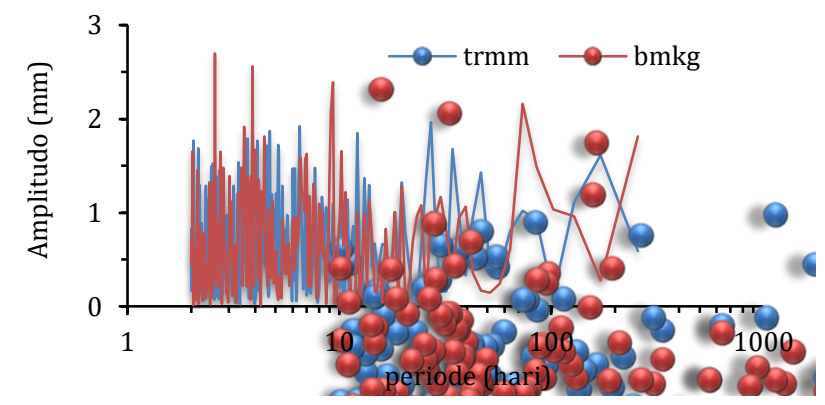

Gambar 3. Spektrum curah hujan harian di stasiun Kemayoran tahun 1998

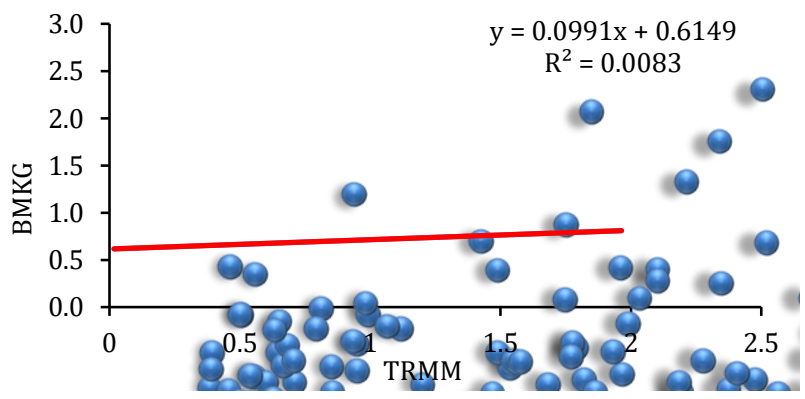

Gambar 4. Hubungan spektrum curah hujan harian antara dari BMKG dan TRMM di Stasiun Kemayoran tahun 1998

Kemudian, Gambar 5 menyajikan spektrum curah hujan harian dari BMKG dan TRRM di stasiun Tanjung Priok pada tahun 1998. Terdapat hubungan yang tidak kuat antara kedua spektrum tersebut, terlihat dari puncak amplitudo antara spektrum BMKG dan TRMM yang tidak mendekati. Pada TRMM puncak amplitudo tertinggi berada di 1,9640 mm sedangkan BMKG berada di 2,2659 mm. Kemudian, Gambar 6 menyajikan model persamaan spektrum curah hujan harian dari BMKG dan TRRM di stasiun Tanjung Priok pada tahun 1998, $Y=0,031 X+0,598$ dengan nilai $R^{2}$ adalah 0,001 . Terlihat hubungan korelasi yang tidak kuat antar kedua spektrum curah hujan tersebut. Tabel 3 menyajikan fungsi persamaan linier spektrum harian curah hujan BMKG dengan TRMM di Stasiun Curah hujan Kemayoran, dengan nilai rata-rata fungsi persamaan yaitu $Y=0,27945 \mathrm{X}$ $+0,56905$ dan nilai $R^{2}$ adalah 0,09.

Tabel 2

Persamaan linear di stasiun Kemayoran

\begin{tabular}{llll}
\hline \multirow{2}{*}{ Tahun } & \multicolumn{3}{l}{ Parameter persamaan linear } \\
\cline { 2 - 4 } & $a$ & $b$ & $R^{2}$ \\
\hline 1998 & 0,099 & 0,614 & 0,008 \\
1999 & 0,037 & 0,626 & 0,002 \\
2000 & 0,128 & 0,456 & 0,028 \\
2001 & 0,327 & 0,484 & 0,104 \\
2002 & 0,543 & 0,391 & 0,265 \\
2003 & 0,327 & 0,578 & 0,095 \\
2004 & 0,417 & 0,422 & 0,168 \\
2005 & 0,317 & 0,451 & 0,120 \\
2006 & 0,360 & 0,553 & 0,101 \\
2007 & 0,337 & 0,663 & 0,090 \\
2008 & 0,310 & 0,573 & 0,084 \\
2009 & 0,462 & 0,480 & 0,124 \\
2010 & 0,212 & 0,552 & 0,043 \\
2011 & 0,196 & 0,387 & 0,048 \\
2012 & 0,415 & 0,461 & 0,189 \\
2013 & 0,559 & 0,411 & 0,272 \\
2014 & 0,408 & 0,774 & 0,106 \\
2015 & 0,48 & 0,664 & 0,111 \\
2016 & 0,269 & 0,658 & 0,052 \\
2017 & 0,167 & 0,611 & 0,025 \\
Rata-Rata & 0,318 & 0,540 & 0,101 \\
\hline
\end{tabular}

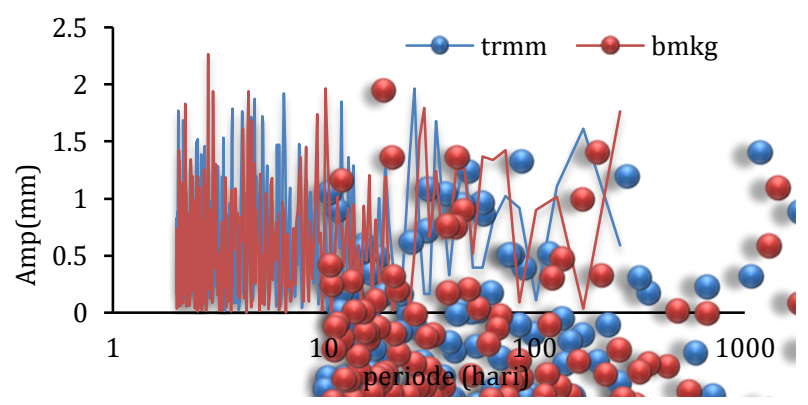

Gambar 5. Spektrum curah hujan harian di stasiun Tanjung Priok tahun 1998

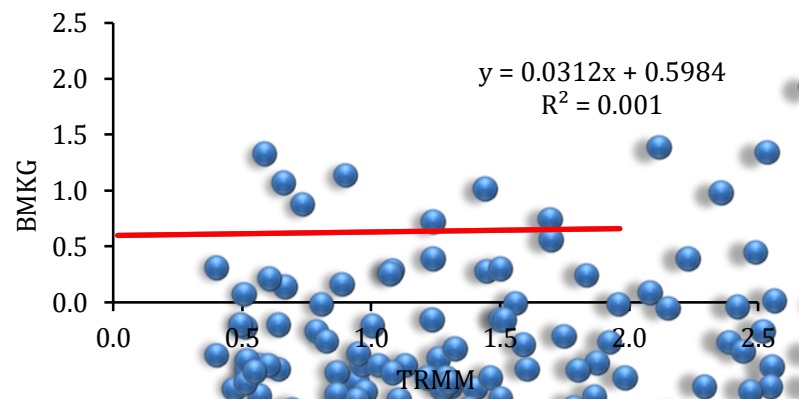

Gambar 6. Hubungan spektrum curah hujan harian antara dari BMKG dan TRMM di Stasiun Tanjung Priok tahun 1998

Untuk mendapatkan nilai korelasi yang lebih baik, maka dicari korelasi kumulatif antara BMKG dengan TRMM dalam spektrum curah hujan 10 harian menggunakan program FFT dengan menggunakan data BMKG dan TRMM di tiga stasiun BMKG Propinsi DKI Jakarta seperti tersebut di atas. Hubungan dapat dilihat pada Gambar 7 - Gambar 12. 
Tabel 3

Persamaan linear di stasiun Tanjung Priok

\begin{tabular}{llll}
\hline Tahun & \multicolumn{3}{l}{ Parameter persamaan linear } \\
\cline { 2 - 4 } & $a$ & $b$ & $R^{2}$ \\
\hline 1998 & 0,031 & 0,598 & 0,001 \\
1999 & 0,060 & 0,569 & 0,005 \\
2000 & 0,194 & 0,441 & 0,064 \\
2001 & 0,323 & 0,644 & 0,065 \\
2002 & 0,580 & 0,412 & 0,280 \\
2003 & 0,297 & 0,532 & 0,082 \\
2004 & 0,373 & 0,453 & 0,155 \\
2005 & 0,299 & 0,378 & 0,132 \\
2006 & 0,210 & 0,547 & 0,048 \\
2007 & 0,215 & 0,663 & 0,042 \\
2008 & 0,435 & 0,384 & 0,214 \\
2009 & 0,368 & 0,508 & 0,086 \\
2010 & 0,147 & 0,546 & 0,024 \\
2011 & 0,336 & 0,307 & 0,152 \\
2012 & 0,453 & 0,351 & 0,229 \\
2013 & 0,179 & 1,060 & 0,019 \\
2014 & 0,259 & 1,012 & 0,035 \\
2015 & 0,323 & 0,673 & 0,075 \\
2016 & 0,132 & 0,645 & 0,018 \\
2017 & 0,155 & 0,666 & 0,019 \\
Rata-Rata & 0,279 & 0,569 & 0,090 \\
\hline & & &
\end{tabular}

Gambar 7 menyajikan spektrum curah hujan kumulatif 10 harian BMKG dan TRRM di stasiun Halim Perdana Kusuma dari tahun 1998-2017. Terlihat kedua puncak PSD tersebut tidak saling mendekati. Pada TRRM, puncak amplitudo tertinggi berada di 39,11 mm sedangkan BMKG puncak amplitudo tertinggi berada di 8,4324 mm. Dan model persamaannya disajikan pada Gambar 8. Terdapat persamaan linier $Y=0,129 X+0,976$ dan nilai $R^{2}$ adalah 0,140 . Terlihat hubungan korelasi yang tidak kuat antara spektrum curah hujan kumulatif 10 harian BMKG dan TRMM.

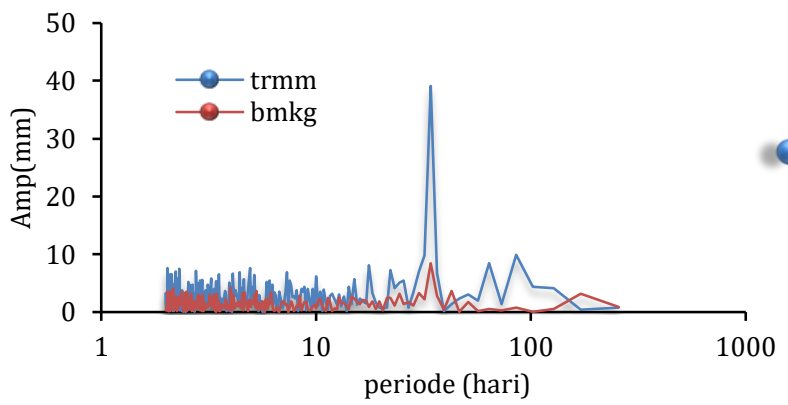

Gambar 7. Korelasi Kumulatif 10 Harian Spektrum TRMM dengan BMKG di Stasiun Halim Perdana Kusuma Tahun 1998-2017

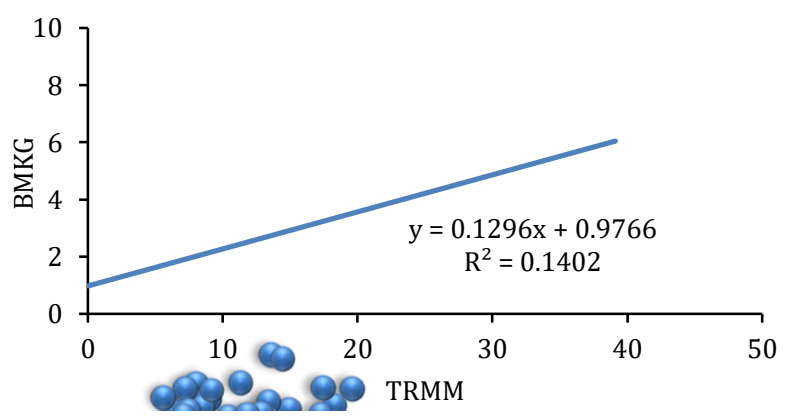

Gambar 8. Hubungan korelasi spektrum curah hujan kumulatif 10 harian BMKG dan TRRM di stasiun Halim Perdana Kusuma Tahun 1998-2017
Kemudian Gambar 9 menyajikan spektrum curah hujan kumulatif 10 harian BMKG dan TRRM di stasiun Kemayoran tahun 1998-2017. Terlihat kedua puncak amplitudo spektrum tersebut saling mendekati. Pada TRMM, puncak amplitudo tertinggi berada di 38,10 mm sedangkan BMKG berada di 39,44 mm. Gambar 10 menyajikan model persamaan kedua spektrum curah hujan tersebut dan terdapat persamaan linier $Y=0,789 X+0,705$ dengan nilai $R^{2}$ adalah 0,539 . Terdapat hubungan korelasi yang sangat kuat antara kedua spektrum tersebut di stasiun Kemayoran.

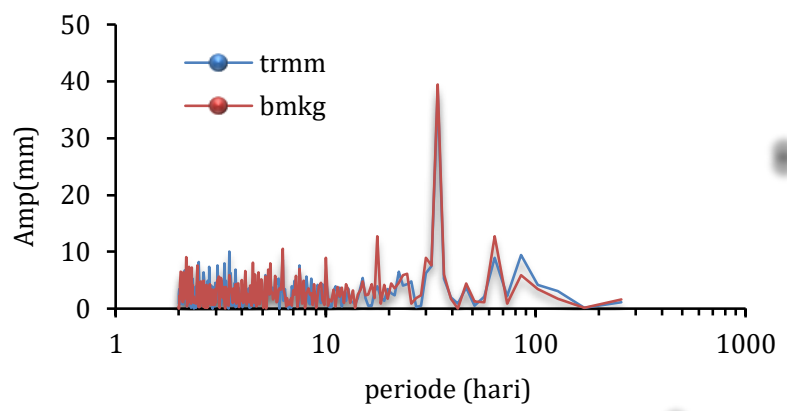

Gambar 9. Korelasi Kumulatif 10 Harian Spektrum TRMM dengan BMKG di Stasiun Kemayoran Tahun 1998-2017

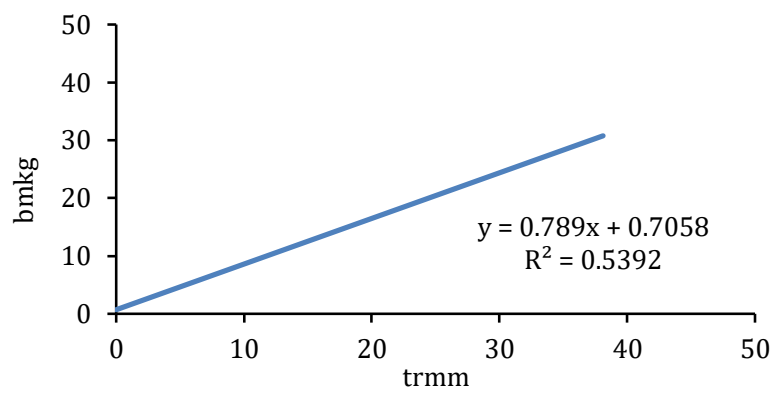

Gambar 10. Hubungan korelasi spektrum curah hujan kumulatif 10 harian BMKG dan TRRM di stasiun Kemayoran Tahun 19982017

Selanjutnya, Gambar 11 menyajikan spektrum curah hujan kumulatif 10 harian BMKG dan TRRM di stasiun Tanjung Priok tahun 1998-2017. Terlihat kedua puncak amplitudo spektrum tersebut saling mendekati. Pada TRMM, puncak amplitudo tertinggi berada di $38,10 \mathrm{~mm}$ sedangkan BMKG berada di 44,94 mm. Gambar 12 menyajikan model persa-maan kedua spektrum curah hujan tersebut dan terdapat persamaan linier $Y=0,842 x+0,513$ dengan nilai $R^{2}$ adalah 0,504 . Terdapat hubungan korelasi yang sangat kuat antara kedua spektrum tersebut di stasiun Tanjung Priok.

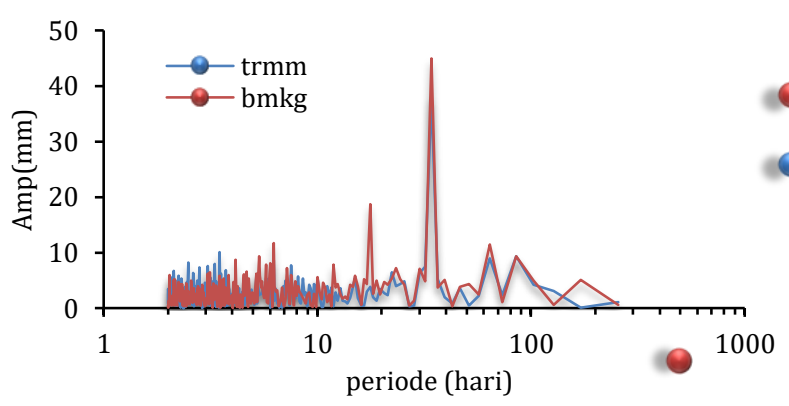

Gambar 11. Grafik Korelasi Kumulatif 10 Harian Spektrum TRMM dengan BMKG di Stasiun Tanjung Priok Tahun 1998-2017 


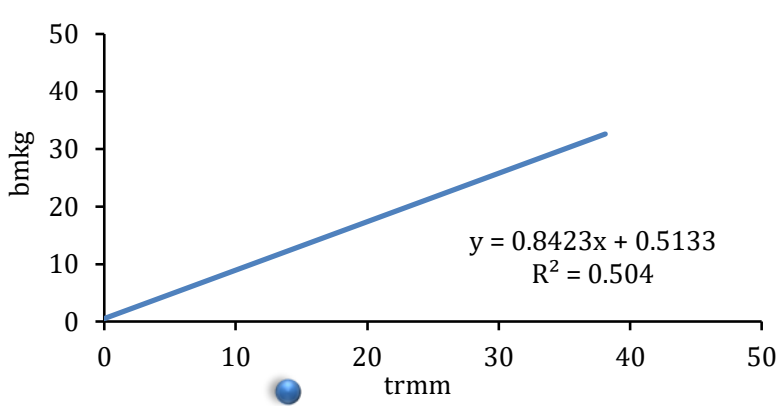

Gambar 12. Hubungan korelasi spektrum curah hujan kumulatif 10 harian BMKG dan TRRM di stasiun Tanjung Priok tahun 19982017

\section{Kesimpulan}

Hasil perhitungan spektrum curah hujan harian, nilai korelasi yang didapat di tiga stasiun curah hujan di Provinsi DKI Jakarta sangat lemah yaitu 0,008, 0,101 dan 0,09 untuk masing-masing stasiun Halim Perdana Kusuma, stasiun Kemayoran dan stasiun Tanjung Priok. Sedangkan untuk spektrum curah hujan kumulatif 10 harian, nilai korelasi yang didapat cukup kuat untuk stasiun Kemayoran dan Tanjung Priok yaitu masing-masing 0,53 dan 0,50. Dari nilai korelasi yang didapat nilai korelasi kumulatif 10 harian lebih baik daripada nilai korelasi harian spektrrum curah hujan BMKG dengan TRMM. Dan dari hasil nilai korelasi tersebut menunjukkan adanya hubungan yang kuat antara spektrum curah hujan BMKG dengan spektrum curah hujan TRMM. Sehingga dari persamaan yang didapat dapat digunakan untuk menghitung amplitudo yang ada di stasiun lain maupun yang tidak tercakup dalam stasiun BMKG di daerah Propinsi DKI Jakarta.

\section{Daftar Pustaka}

[1] Shukla, J.: Effect of Arabian sea-surface temperature anomaly on Indian summer monsoon: A numerical experiment with the GFDL model. Journal of Atmospheric Sciences, 32,3, 1975 , 503-511.

[2] Frankignoul, C.: Sea surface temperature anomalies, planetary waves, and air-sea feedback in the middle latitudes. Reviews of geophysics, 23, 4, 1985, 357-390.

[3] Findell, K.L., Pitman, A.J., England, M.H., Pegion, P.J.: Regional and global impacts of land cover change and sea surface temperature anomalies. Journal of Climate, 22, 12, 2009. 3248-3269.

[4] Teegavarapu, R. S., Chandramouli, V.: Improved weighting methods, deterministic and stochastic data-driven models for estimation of missing precipitation records. Journal of hydrology, 312, 4, 2005, 191-206.

[5] Chowdhury, A.K., Kar, K.K., Shahid, S., Chowdhury, R., Rashid, M.M.: Evaluation of spatio-temporal rainfall variability and performance of a stochastic rainfall model in Bangladesh. International Journal of Climatology, 39,11, 2019, 4256-4273.

[6] Kawanishi, T., Kuroiwa, H., Kojima, M., Oikawa, K., Kozu, T., Kumagai, H., Nishikawa, K.: Precipitation radar onboard the Tropical Rainfall Measuring Mission (TRRM) satellite. In IGARS 1998 - Sensing and Managing the Environment. 1998 IEEE International Geoscience and Remote Sensing, 4 1998, 1876-1878.

[7] Schumacher, C., Houze Jr, R.A.: Comparison of radar data from the TRMM satellite and Kwajalein oceanic validation site. Journal of applied meteorology, 39, 12, 2000, 21512164.

[8] Erazo, B., Bourrel, L., Frappart, F., Chimborazo, O., Labat, D., Granda, L.D., Matamoros, D., Mejia, R.: Validation of satellite estimates (tropical rainfall measuring mission, TRMM) for rainfall variability over the pacific slope and coast of ecuador. Water, 10, 2, 2018, 213. 